\title{
EPAC Inhibition of SUR1 Receptor Increases Glutamate Release and Seizure Vulnerability
}

\author{
Kunpeng Zhao, ${ }^{1 *}$ Ruojian Wen, ${ }^{1 \star}$ Xiaoxi Wang, ${ }^{1}$ Lei Pei, ${ }^{1}$ Ying Yang, ${ }^{1,3}$ You Shang, ${ }^{2}$ Nicolas Bazan, ${ }^{3}$ Ling-Qiang Zhu, ${ }^{1}$ \\ Qing Tian, ${ }^{1}$ and Youming $\mathrm{Lu}^{1,2,3}$ \\ ${ }^{1}$ Key Laboratory of Neurological Disease, Ministry of Education, Huazhong University of Science and Technology Tongji Medical College, Wuhan, 430030 \\ China, ${ }^{2}$ Translational Research Center, the Union Hospital, Huazhong University of Science and Technology Tongji Medical College, Wuhan, 430022 China, \\ and ${ }^{3}$ Neuroscience Center of Excellence and Department of Neurology, Louisiana State University School of Medicine, New Orleans, Louisiana 70112
}

EPAC (Exchange Proteins Activated by cAMP) regulates glutamate transmitter release in the central neurons, but a role underlying this regulation has yet to be identified. Here we show that EPAC binds directly to the intracellular loop of an ATP-sensitive potassium $\left(\mathrm{K}_{\mathrm{ATP}}\right)$ channel type-1 sulfonylurea receptor (SUR1) receptor consisting of amino acids $859-881$ (SUR ${ }^{859-881}$ ). Ablation of EPAC or expression of SUR $1^{859-881}$, which intercepts EPAC-SUR1 binding, increases the open probability of $\mathrm{K}_{\mathrm{ATP}}$ channels consisting of the Kir6.1 subunit and SUR1. Opening of $\mathrm{K}_{\mathrm{ATP}}$ channels inhibits glutamate release and reduces seizure vulnerability in adult mice. Therefore, EPAC interaction with SUR1 controls seizure susceptibility and possibly acts via regulation of glutamate release.

\section{Introduction}

EPAC (Exchange Proteins Activated by cAMP) belongs to a novel class of cAMP receptors (de Rooij et al., 1998; Bos, 2006). There are two isoforms of EPAC proteins and each has multiple domains, consisting of one (EPAC1) or two (EPAC2) cAMP regulatory binding motifs (Kawasaki et al., 1998; Rehmann et al., 2003). Both EPAC1 and EPAC2 proteins are expressed throughout the brain, including in the hippocampus, striatum, and prefrontal cortex (Zhang et al., 2009; Yang et al., 2012). To determine their neurological functions, we developed mutant strains of mice with deficiency in expression of either EPAC1 $\left(\mathrm{EPAC1}^{-/-}\right)$ or EPAC2 $\left(\mathrm{EPAC}^{-/-}\right)$or both $\left(\mathrm{EPAC}^{-/-}\right)$genes (Yang et al., 2012). We showed previously that combined deletion of both the $\mathrm{EPAC} 1$ and EPAC2 genes $\left(\mathrm{EPAC}^{-1-}\right.$ ) reduces glutamate release from the presynaptic terminals (Yang et al., 2012).

Transmitter release involves several steps of interactions between synaptic and vesicle fusion proteins (Südhof, 1995; Schneggenburger and Neher, 2005; Haucke et al., 2011) and requires $\mathrm{Ca}^{2+}$ influx into the terminals (Stanley, 1997; Jackson and Chapman, 2008). Previously, we described ATP-sensitive potassium $\left(\mathrm{K}_{\mathrm{ATP}}\right)$ channels consisting of Kir6.1 subunit and type-1

Received Dec. 13, 2012; revised Feb. 10, 2013; accepted Feb. 15, 2013.

Author contributions: R.W., L.-Q.Z., Q.T., and Y.L. designed research; K.Z., R.W., X.W., L.P., Y.Y., and Y.S. performed research; K.Z., N.B., L.-Q.Z., Q.T., and Y.L. analyzed data; K.Z., R.W., L.-Q.Z., Q.T., and Y.L. wrote the paper.

This work was supported by National Natural Science Foundation of China (Grants 81130079 and 91232302 to Y.L., 81200863 to L.P., and 81271404 to Q.T.), New Century Excellent Talent (Grant NCET-100241 to L.-Q.Z.), Ministry of Science and Technology of China (Grant 2011DFG33250 to L.-Q.Z.), and the National Institute on Aging-National Institutes of Health (Grant R01AG033282 to Y.L.).

*K.Z. and R.W. contributed equally to this work.

The authors declare no competing financial interests.

Correspondence should be addressed to one of the following: Ling-Qiang Zhu, Qing Tian, or Youming Lu, Key Laboratory of Neurological Disease, Ministry of Education, Huazhong University of Science and Technology Tongji Medical College, Wuhan, 430030 China. E-mail: zhulq@mail.hust.edu.cn, tianq@mail.hust.edu.cn, or lym@mail.hust.edu.cn.

DOI:10.1523/JNEUROSCI.5686-12.2013

Copyright $\odot 2013$ the authors $\quad 0270-6474 / 13 / 338861-05 \$ 15.00 / 0$ sulfonylurea receptor (SUR1) at the presynaptic terminals in the hippocampus (Soundarapandian et al., 2007). $\mathrm{K}_{\mathrm{ATP}}$ channels are gated by metabolic factors such as ATP/ADP ratios (Ashcroft and Gribble, 1998; Schwappach et al., 2000). In pancreatic $\beta$-cells, $\mathrm{K}_{\mathrm{ATP}}$ channels are associated directly with EPAC2 protein and thus control $\mathrm{Ca}^{2+}$-dependent secretion of insulin (Zhang et al., 2009). However, whether EPAC interacts with $K_{\mathrm{ATP}}$ channels in the central neurons is not known.

In the present study, we used a gene-targeting approach combined with electrophysiological recordings to show that EPAC physically and functionally interacts with $\mathrm{K}_{\mathrm{ATP}}$ channels via direct inhibition of the SUR1 receptor in the dentate granule cells. We found that this inhibition controls glutamate release and seizure vulnerability in adult mice.

\section{Materials and Methods}

Development of EPAC mutant mice. The conditional mutant strain of mice with a selective deletion of EPAC1 gene in the hippocampus $\left(\mathrm{EPAC1}^{-l-}\right.$ mice) was generated by gene targeting in $129 \mathrm{~Sv}$ embryonic stem cells, as described previously (Yang et al., 2012). EPAC2-null mutant $\left(\mathrm{EPAC} 2^{-l-}\right)$ mice were generated using a gene-trapping approach in 129Sv mouse embryonic stem cells (Yang et al., 2012). A double mutant strain of mice (EPAC ${ }^{-1-}$ mice) was developed by crossing $\mathrm{EPAC}^{-/-}$mice with $\mathrm{EPAC} 2^{-/-}$mice. SUR $1^{-1-}$ mice were purchased from The Jackson Laboratory and bred with $\mathrm{EPAC}^{-1-}$ mice, resulting in the $\mathrm{EPAC}^{-1-} / \mathrm{SUR} 1^{-/-}$mice. Care and experiments with animals were in accordance with institutional guidelines and those of the animal care and use committees of Huazhong University of Science and Technology (Wuhan, China) and the Louisiana State University Health Sciences Center (New Orleans).

Co-IP experiments. Synaptosomes were prepared as described previously (Peng et al., 2006; Soundarapandian et al., 2007). Briefly, the hippocampal homogenate in $0.32 \mathrm{M}$ sucrose was centrifuged for $10 \mathrm{~min}$ at $1400 \times g$ to yield a pellet (P1) and a supernatant (S1). S1 was centrifuged for another $10 \mathrm{~min}$ at $13,800 \times \mathrm{g}$, yielding a crude synaptosomal pellet (P2) and a supernatant (S2). P2 was resuspended in $0.32 \mathrm{M}$ sucrose con- 
taining $1 \mathrm{~mm} \mathrm{NaHCO}$ and layered on top of a discontinuous sucrose gradient $(0.8,1.0$, and $1.2 \mathrm{M}$ ). After centrifugation for $2 \mathrm{~h}$ at $82,500 \times$ $g$, the synaptosomes were recovered as a band, resuspended in $0.32 \mathrm{~m}$ sucrose and $1 \mathrm{~mm}$ $\mathrm{NaHCO}_{3}$ plus protease inhibitors, pelleted, and resuspended in HEPES buffer containing protease inhibitors.

Synaptosomes were incubated with $1 \%$ Triton X-100 for $20 \mathrm{~min}$ on ice and centrifuged at $14,000 \mathrm{~g}$ for $15 \mathrm{~min}$ to obtain the supernatant. Protein concentration in the extracts was determined by Lowry assay (Bio-Rad). The extracts $(\sim 500 \mu \mathrm{g}$ of protein) were incubated with polyclonal rabbit anti-EPAC1 $(2 \mu \mathrm{g})$ or anti-EPAC2 $(2 \mu \mathrm{g})$ overnight at $4^{\circ} \mathrm{C}$, followed by the addition of $40 \mu \mathrm{l}$ of Protein G-Sepharose (Sigma) for $3 \mathrm{~h}$ at $4^{\circ} \mathrm{C}$. Immunoprecipitates were washed four times with PBS, denatured with SDS sample buffer, separated by SDSPAGE, and blotted with anti-Kir6.1 (1:100; Santa Cruz Biotechnology), anti-SUR1, or antisyntaxin-1A (1:400; Santa Cruz Biotechnology) antibodies.

Electrophysiology. The slices $(350 \mu \mathrm{m})$ of the hippocampus were cut from male mice at $90 \pm$ $5 \mathrm{~d}$ of age and placed in a holding chamber for at least $1 \mathrm{~h}$. A single slice was then transferred to the recording chamber and submerged and perfused with artificial CSF $(2 \mathrm{ml} / \mathrm{min})$ that had been saturated with $95 \% \mathrm{O}_{2} / 5 \% \mathrm{CO}_{2}$. The composition of the artificial CSF was as follows (in $\mathrm{mM}$ ): $124 \mathrm{NaCl}, 3 \mathrm{KCl}, 1.25 \mathrm{NaH}_{2} \mathrm{PO}_{4}, 2$ $\mathrm{MgCl}_{2}, 2 \mathrm{CaCl}_{2}, 26 \mathrm{NaHCO}_{3}$, and 10 dextrose. Whole-cell patch-clamp recordings $(5 \mathrm{M} \Omega)$ at voltage-clamp mode were visualized with infrared differential interference contrast using an Axioskop 2FS equipped with Hamamatsu C2400-07E optics, as described previously (Peng et al., 2006; Tu et al., 2010; Yang et al., 2012).

The internal pipette solution for whole-cell patch-clamp recordings contained the following (in $\mathrm{mm}$ ): 132.5 cesium gluconate, 17.5 $\mathrm{CsCl}, 0.05$ EGTA, 10 HEPES, $2 \mathrm{Mg}$-ATP, and 0.5 GTP, pH 7.4 (290 mOsm). NMDA receptor-mediated EPSCs were evoked by paired-pulse stimulation of the mossy fiber tracks in the hilus of the dentate gyrus using bipolar tungsten electrodes and recorded with Axopatch $200 \mathrm{~B}$ amplifiers and monitored by computer using $p$ Clamp 11 at $35^{\circ} \mathrm{C}$ in the presence of $10 \mu \mathrm{m}$ bicuculline and $20 \mu \mathrm{M}$ NBQX at a holding potential of $+60 \mathrm{mV}$. The spontaneous EPSCs were recorded in the presence of 100 $\mu \mathrm{M}$ AP5 and $10 \mu \mathrm{M}$ bicuculline at a holding potential of $-70 \mathrm{mV}$. The threshold $(\sim 6 \mathrm{pA})$ for detection was set at $3 \times$ the baseline SD from a template of $0.5 \mathrm{~ms}$ rise time and $10 \mathrm{~ms}$ decay. Cells with a noisy or unstable baseline ( 5 min after break-in) were discarded.

For single-channel recordings from the dentate granule cell in the hippocampus, the pipette solution contained the following (in $\mathrm{mm}$ ): 140 potassium methanesulfonate (KMeS), $10 \mathrm{HEPES}, 2 \mathrm{CaCl}_{2}, 10 \mathrm{TEA}-\mathrm{Cl}, 2$ $\mathrm{CsCl}, 1$ 4-aminopyridine (4-AP), $100 \mathrm{~nm}$ charybdotoxin, and $100 \mathrm{~nm}$ aparmin, pH 7.4 (290 mOsm).

Generation of $r A A V 1 / 2$ virus particles. SUR1 ${ }^{859-881}$ (dhlmqagilellrddkrtvvlvt) and its scrambled control (lmqdhllrdagilellvlvtkrt) were cloned into the rAVE construct containing eGFP through ApaI/KpnI (GenDe-
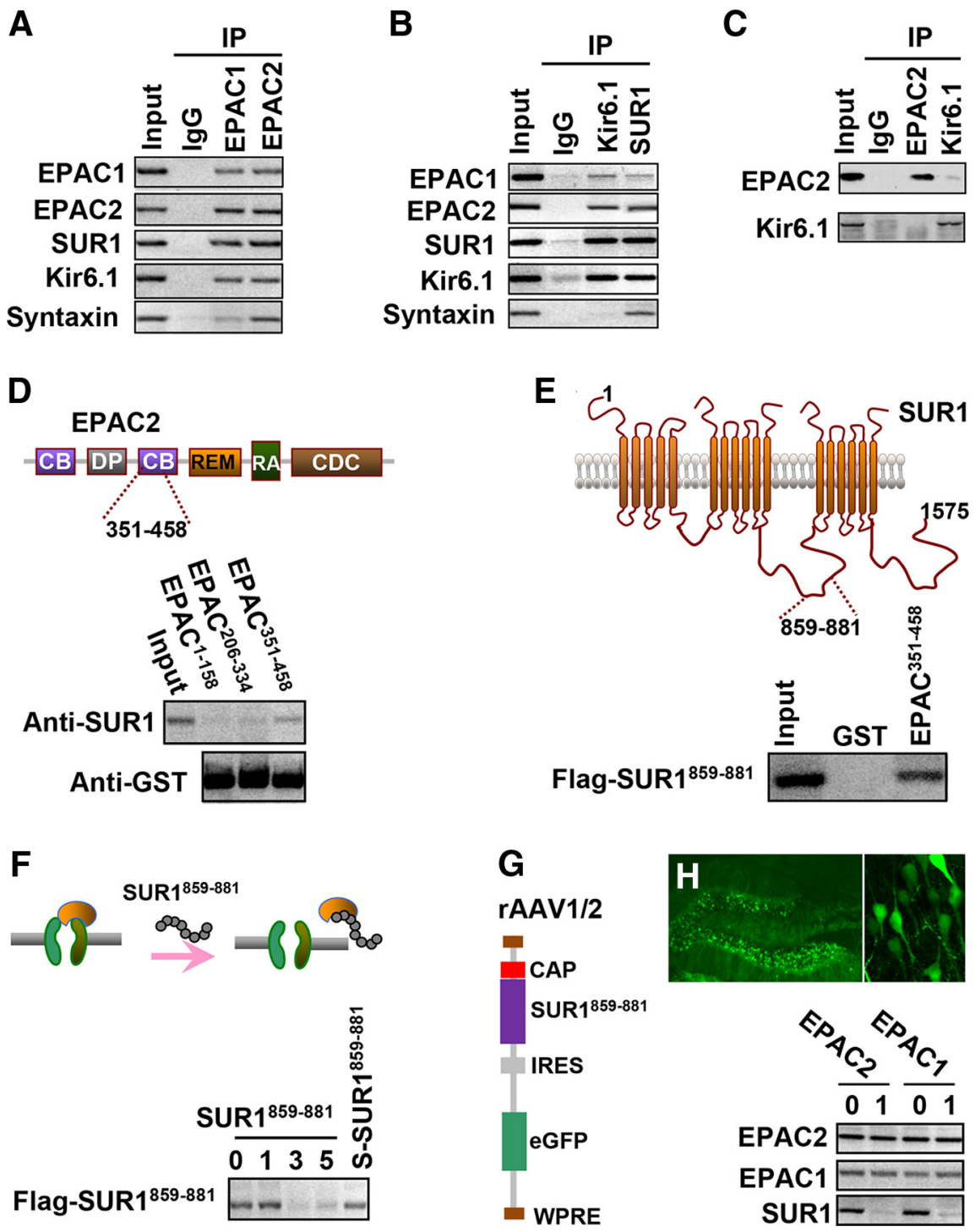

Figure 1. EPAC binds to SUR1 directly. $A-C$, Synaptosomes were prepared from SUR $1^{+/+}$mice $(A, B)$ and SUR $1^{-1-}$ mice $(C)$ and precipitated using antibodies against EPAC1 and EPAC2 or Kir6.1 and SUR1, as indicated. The precipitates were blotted with antibodies against EPAC1, EPAC2, SUR1, Kir6.1, and syntaxin-1A. Input: $20 \mu \mathrm{g}$ of proteins without precipitation were loaded. Similar results were seen in each of the four experiments. D, Synaptosomes were precipitated using GST-EPAC2 ${ }^{1-158}$, GSTEPAC2 ${ }^{206-334}$, or GST-EPAC2 $2^{351-458}$ and blotted with anti-SUR1. Input: $20 \mu \mathrm{g}$ of protein without precipitation was blotted with antibodies against GST and SUR1, as indicated. Similar results were seen in each of the four experiments. E, GST-EPAC2 ${ }^{351-458}$ or GST alone was coexpressed with Flag-tagged SUR1 ${ }^{859-881}$ in HEK293 cells. Then, $72 \mathrm{~h}$ after expression, cell lysates were precipitated using anti-GST and blotted with anti-Flag antibody. Input: $10 \mu \mathrm{g}$ of proteins without precipitation were loaded. Similar results were seen in each of the four experiments. F, GST-EPAC2 ${ }^{351-458}$ was coexpressed with Flag-tagged SUR1 $1^{859-881}$ in HEK293 cells. Then, $72 \mathrm{~h}$ after expression, cell lysates were precipitated using anti-GST in the presence of $5 \mu \mathrm{g} / \mathrm{ml} \mathrm{SUR} 1^{859-881}$ peptide or its scrambled control (S-SUR1 ${ }^{859-881}$ ) and blotted with anti-Flag antibody. Similar results were seen in each of the five experiments. $\boldsymbol{G}, \boldsymbol{H}$, The rAAV1/2 vector $(\boldsymbol{G})$ for expression of SUR1 ${ }^{859-881}$ and a representative image $(\boldsymbol{H})$ of the dentate gyrus area taken $15 \mathrm{~d}$ after injection of the rAAV1/2-CAP/SUR1 ${ }^{859-881}$-IRES-EGFP virus particles. Synaptosomes were prepared from the dentate gyrus $15 \mathrm{~d}$ after expression of SUR1 ${ }^{859-881}$ (lane 1 ) or its scrambled control (lane 0 ) and precipitated with anti-EPAC1 and anti-EPAC2, respectively. The precipitates were blotted with antibodies againstEPAC1, EPAC2, or SUR1, as indicated. Similar results were seen in each of the five experiments.

tect), creating rAVE-CAP/ SUR1 ${ }^{859-881}$-IRES-eGFP vectors. The rAVE plasmids were cotransfected with the AAV helper1 and helper 2 into HEK293 cells to generate the rAAV1/2 virus particles. Generation of the infectious virus particles $\left(>5 \times 10^{12}\right.$ genomic particle/ml $)$ were described previously (Peng et al., 2006; Tu et al., 2010). Activated virus particles were coded by experimenters. Other experimenters, who were unaware of the coded particles, injected the particles $(2 \mu \mathrm{l}$ at $0.2 \mu \mathrm{l} / \mathrm{min})$ into each side of the dorsal hippocampus ( $3.1 \mathrm{~mm}$ posterior to bregma; $2.3 \mathrm{~mm}$ lateral to the midline; $2.9 \mathrm{~mm}$ below dura). 
Kainic acid treatment and behaviors. Adult male mice (age $90 \pm 5 \mathrm{~d}$, $28 \pm 2$ g of body weight) were injected intraperitoneally with a single dose of kainic acid (KA; $25-40 \mathrm{mg} / \mathrm{kg}$ in PBS, A.G. Scientific). Mice were monitored continuously for $3 \mathrm{~h}$. The severity of seizures was rated by the arbitrary scale, with $1=$ staring and immobility/wet dog shake, $2=$ hyperactivity, repetitive movements, rearing, and falling, $3=$ low seizures (intense shivering), $4=$ severe tonic/clonic convulsion, and $5=$ death. The averaged points for seizure severity in a given group were expressed as the seizure index, as described previously (Soundarapandian et al., 2007).

Statistical analysis. Data were analyzed using SPSS 11.0 statistical software. All data are expressed as mean \pm SEM. Statistical significance was determined by one-way ANOVA followed by a Student-Newman-Keuls post hoc test with $95 \%$ confidence and Student's two-tailed $t$ test.

\section{Results}

EPAC2 ${ }^{351-458}$ binds to SUR1 ${ }^{859-881}$

To search for an interaction between EPAC and $\mathrm{K}_{\mathrm{ATP}}$ channels, we precipitated the EPAC protein complex in the hippocampus of adult mice. Blots of the precipitates revealed that EPAC proteins were physically associated with the $\mathrm{K}_{\mathrm{ATP}}$ channel components, including the Kir6.1 subunit and the SUR1 receptor (Fig. $1 A, B)$. This association was eliminated in SUR $1^{-1-}$ mice (Fig. $1 C)$, revealing that the SUR1 receptor acts as an intermediary between EPAC and Kir6.1 channels. As a positive control, we blotted the precipitates with anti-syntaxin-1A, a functional component of synaptic vesicle proteins that is known to interact with SUR1 receptor in the central neurons (Chang et al., 2011; Zhou et al., 2012). To validate this association, we generated a series of truncation mutants of SUR1 and EPAC proteins (Fig. $1 D, E$ ) and found that a GST-EPAC2 protein consisting of amino acids 351458 (GST-EPAC2 ${ }^{351-458}$ ) was able to pull down endogenous SUR1 receptor in synaptosomes from the hippocampus of adult mice (Fig. 1D). Coexpression of GST-EPAC2 ${ }^{351-458}$ with FlagSUR1 ${ }^{859-881}$ in HEK293 cells revealed that the EPAC2 protein bound directly to the SUR1 receptor (Fig. $1 E$ ). Direct binding between GST-EPAC2 $2^{351-458}$ and Flag-SUR $1^{859-881}$ was verified by a peptide-blocking experiment (Fig. $1 F$ ) in which a synthesized SUR $1^{859-881}$ peptide at a concentration of $5 \mu \mathrm{g} / \mathrm{ml}$ sufficiently inhibited an association of GST-EPAC2 $2^{351-458}$ with Flag-SUR $1^{859-881}$. To examine whether SUR1 ${ }^{859-881}$ intercepts EPAC association with SUR1 in brain cells in vivo, we expressed SUR1 ${ }^{859-881}$ in the hippocampus of adult mice using the rAAV1/2 virus vector (Fig. $1 G$ ). Fifteen days after expression, we precipitated endogenous EPAC proteins. Western blots of the precipitates revealed that SUR $1^{859-881}$ uncoupled EPAC proteins from SUR1 receptor in the hippocampus (Fig. $1 H$ ), demonstrating that EPAC is physically associated with $\mathrm{K}_{\mathrm{ATP}}$ channels via direct binding between EPAC2 ${ }^{351-458}$ and SUR1 ${ }^{859-881}$.

Increased open probability of $\mathrm{K}_{\mathrm{ATP}}$ channels in EPAC $^{-/-}$mice

$\mathrm{K}_{\text {ATP }}$ channels consist of inwardly rectifying $\mathrm{K}^{+}$channels (Kir6.1, Kir6.2) and regulatory sulfonylurea receptors (SUR1, SUR2A, and SUR2B), which are members of the ATP-binding cassette proteins (Ashcroft and Gribble, 1998; Schwappach et al., 2000). A combination of the different subunits forms different types of $\mathrm{K}_{\text {ATP }}$ channels in different cell types. We showed previously that the presynaptic $\mathrm{K}_{\mathrm{ATP}}$ channel consists of the Kir6.1 subunit and the SUR1 receptor in the hippocampus (Soundarapandian et al., 2007). Therefore, we investigated here whether EPAC regulates the Kir6.1/SUR1 type of $\mathrm{K}_{\mathrm{ATP}}$ channels functionally. We performed single-channel recordings in the dentate granule cells of $\mathrm{EPAC}^{-1-}$ mice and compared them with $\mathrm{EPAC}^{+/+}$mice (Fig.
A

$\mathrm{EPAC}^{+/+}$

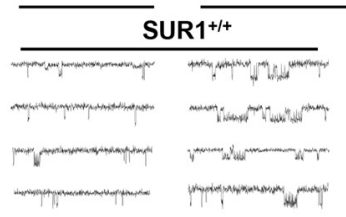

EPAC $^{-1-}$

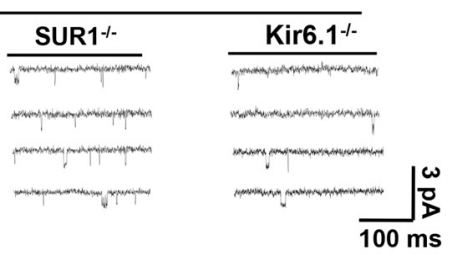

B
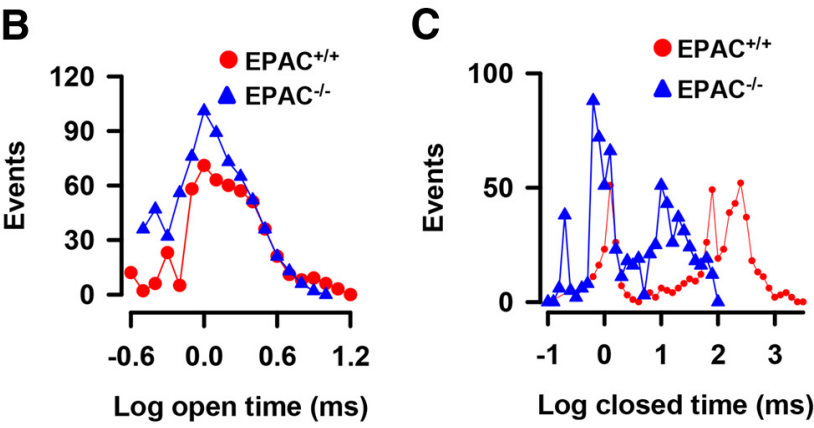

Log closed time (ms)
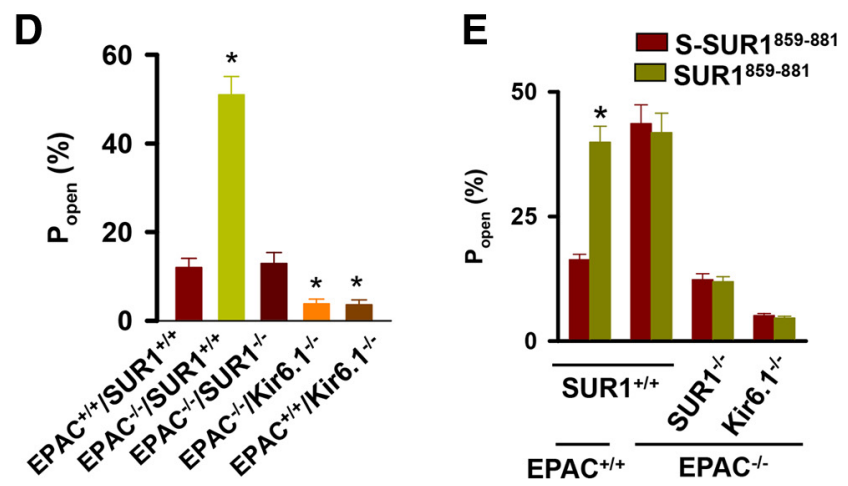

Figure 2. Deletion EPAC increases $K_{A T P}$ channel open probability. $A$, Traces are representative single-channel recordings from the dentate granule cells. Downward deflections of the current traces indicate single-channel openings. $\boldsymbol{B}, \boldsymbol{C}$, Graphs of open $(\boldsymbol{B})$ and closed $(\boldsymbol{C})$ time distributions of single $K_{A T P}$ channel currents. $D$, Bar graph summarizes single-channel currents in cell-attached patches from the dentate granule neurons of $\mathrm{EPAC}^{+/+} / \mathrm{SUR}^{+/+}, \mathrm{EPAC}^{-/-}$/ $\mathrm{SUR}^{+/+}$, and EPAC ${ }^{-/-} / \mathrm{SUR} 1^{-1-}$ mice. Data are mean $\pm \mathrm{SEM}(n=8$ recordings $/ 4$ mice/ genotypes, $\left.{ }^{*} p<0.01\right)$. $E$, Interception of EPAC-SUR1 binding increases $K_{\text {ATP }}$ channel open probability. The $K_{\text {ATP }}$ single-channel currents were recorded from the dentate granule cells $15 \mathrm{~d}$ after expression of SUR ${ }^{859-881}$ or its scrambled control. Data are mean \pm SEM $(n=8$ recordings/4 mice/genotypes, ${ }^{*} p<0.01$ ).

$2 A)$. Open- and closed-channel distributions are shown in Figure $2 B, C$. We found that genetic deletion of EPAC genes increased open probability $\left(P_{\text {open }}\right)$ of $\mathrm{K}_{\mathrm{ATP}}$ channels. This increase was absent in both SUR $1^{-l-}$ and Kir6.1 $1^{-l-}$ mice (Fig. 2D). An increase of $P_{\text {open }}$ was also seen in the wild-type mice expressing SUR1 ${ }^{859-881}$ (Fig. 2E), indicating that EPAC proteins regulate $\mathrm{K}_{\mathrm{ATP}}$ channel open probability via a direct inhibition of the SUR1 receptor.

\section{Reduced glutamate release probability in $\mathrm{EPAC}^{-1-}$ mice}

Our prior studies showed that SUR1 receptor is associated with synaptic vesicle proteins at the presynaptic terminals (Soundarapandian et al., 2007). We thus investigated here whether an increase of $\mathrm{K}_{\mathrm{ATP}}$ channel open probability in $\mathrm{EPAC}^{-1-}$ mice alters glutamate transmitter release. We first analyzed the spontaneous EPSCs and found that their frequency was reduced in EPAC ${ }^{-1-}$ mice compared with wild-type controls, whereas the mean amplitude did not differ between genotypes (Fig. $3 A-D$ ). We next recorded the paired-pulse facilitation of the evoked EPSCs at mossy fiber-CA3 synapses. To measure glutamate release from 
the mossy-fiber terminal accurately and to avoid the polysynaptic responses within CA3-CA3 synaptic inputs, we recorded NMDA-receptor-mediated EPSCs in the presence of $20 \mu \mathrm{M}$ NBQX. We found that $\mathrm{EPAC}^{-1-}$ mice displayed greater paired-pulse facilitation than wild-type controls, with the greatest effects at the shortest interstimulus interval (Fig. $3 E, F)$. This facilitation increased with an elevation of $\mathrm{Ca}^{2+}$ (Fig. 3G). Therefore, $\mathrm{EPAC}^{-1-}$ mice have a reduction of $\mathrm{Ca}^{2+}$ dependent glutamate release probability at the mossy-fiber terminals. The similar reduction of glutamate release was achieved by interception of EPAC-SUR1 association via expressing SUR1 ${ }^{859-881}$ peptide. Therefore, an interaction between EPAC and the SUR1 receptor regulates $\mathrm{Ca}^{2+}$-dependent glutamate release.

\section{Reduced seizure vulnerability in EPAC $^{-1-}$ mice}

Our earlier study revealed that, compared with the wild-type controls, mutant mice lacking the SUR1 gene (SUR1 ${ }^{-/-}$) or the Kir6.1 gene (Kir6.1 ${ }^{-/-}$) are vulnerable to epileptic seizures (Soundarapandian et al., 2007), a severe neurological disorder that is known to be associated with an increased glutamate release (Ben-Ari and Cossart, 2000). We thus hypothesized that an increase of $\mathrm{K}_{\mathrm{ATP}}$ channel open probability in $\mathrm{EPAC}^{-1-}$ mice reduces seizure sensitivity. To test this hypothesis, we examined adult mice for seizure activity after KA administration. The latency and severity of seizures were diagnosed and expressed as a seizure index with increased KA doses (Fig. 4A). We found that the majority of $\mathrm{EPAC}^{+/+}$mice $(96 \%, n=15$ mice) underwent status epileptic seizures such as hyperactivity, constant rearing, and falling. Eleven of 15 mice exhibited tonic convulsion and died within $3 \mathrm{~h}$ when a single dose of $40 \mathrm{mg} / \mathrm{kg}$ was administered (Fig. 4A). When a single dose of $30 \mathrm{mg} / \mathrm{kg}$ was administered, the seizure index of $\mathrm{EPAC}^{+/+}$mice was of $3.62 \pm 0.51$ (mean \pm SEM, $n=15$, Fig. $4 B$ ). In striking contrast, few EPAC $^{-1-}$ mice progressed in severity to the extent of $\mathrm{EPAC}^{+/+}$mice; 10 of 11 EPAC $^{-1-}$ mice had no convulsive responses and remained alive throughout the course of observations with a seizure index of $1.38 \pm 0.16($ mean \pm SEM, $n=11)$. The similar reduction of epileptic seizures was observed in wild-type mice expressing SUR1 ${ }^{859-881}$ (Fig. 4B). Therefore, EPAC protein confers seizure vulnerability through direct inhibition of the SUR1 receptor.

\section{Discussion}

In our previous studies (Soundarapandian et al., 2007), we reported that a combination of the Kir6.1 subunit with the SUR1 receptor form neuronal-type $\mathrm{K}_{\mathrm{ATP}}$ channels that are located predominantly at the presynaptic terminals. Genetic inhibition of either the Kir6.1 subunit or the SUR1 receptor enhances glutamate transmitter release, leading to the induction of epileptic seizures in adult mice (Soundarapandian et al., 2007). In the present study, we identified EPAC proteins as the functional interactive components of the Kir6.1/SUR1 type of $\mathrm{K}_{\mathrm{ATP}}$ channels
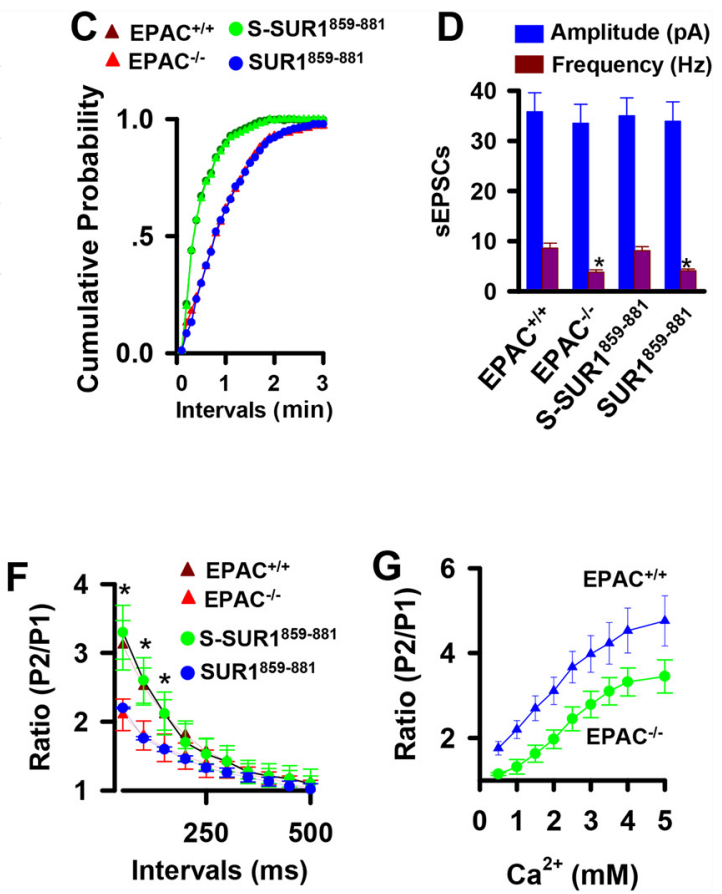

Figure 3. EPAC inhibition of SUR1 reduces glutamate release. $\boldsymbol{A}-\boldsymbol{D}$, Representative spontaneous EPSCS $(\boldsymbol{A})$, averaged responses $(\boldsymbol{B})$, cumulative probability $(\boldsymbol{C})$, and average frequency and amplitude $(\boldsymbol{D})$ in $C A 3$ pyramidal neurons of EPAC ${ }^{+/+}$, EPAC ${ }^{-/-}$, and EPAC ${ }^{+1+}$ mice expressing SUR ${ }^{859-881}$ or scrambled SUR $1^{859-881}$. Data are mean \pm SEM $(n=12$ recording/6 mice per genotype, $\left.{ }^{*} p<0.01\right)$. All recordings are at a hold potential of $-70 \mathrm{mV}$. $\boldsymbol{E}$, Representative NMDA-receptor-mediated EPSCs from

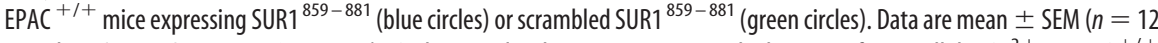
recordings $/ 6$ mice/genotype, $\left.{ }^{*} p<0.01\right)$. G. The paired-pulse ratios increase with elevation of extracellular $\mathrm{Ca}^{2+}$ in EPAC ${ }^{+/+}$ green circles). Data are mean \pm SEM $(n=9$ recordings $/ 3$ mice/genotype)

in the dentate granule cells. Genetic deletion of EPAC genes or disruption of EPAC-SUR1 interaction increased the open probability of $\mathrm{K}_{\mathrm{ATP}}$ channels substantially, thus counteracting epileptic seizures occurring in the SUR1 ${ }^{-1-}$ mice. This finding indicates that EPAC controls $\mathrm{K}_{\mathrm{ATP}}$ channel activity via tonic inhibition of the SUR1 receptor at the presynaptic terminals, as illustrated in Figure 4C, D.

Previous studies using pharmacological reagents showed that the EPAC protein regulates vesicular release probability in the central neurons (Sakaba and Neher, 2003; Zhong and Zucker, 2005), but the mechanism underlying this regulation remained unknown. In the present study, we have shown that EPAC proteins are associated with $\mathrm{K}_{\mathrm{ATP}}$ channels via a direct binding between EPAC2 and the SUR1 receptor. $\mathrm{K}_{\mathrm{ATP}}$ channels are gated by intracellular metabolic factors and opening of the channels hyperpolarizes cells, leading to a reduction of $\mathrm{Ca}^{2+}$-dependent transmitter release (Fig. 4C). An increase of intracellular $\mathrm{Ca}^{2+}$ could be caused by either $\mathrm{Ca}^{2+}$ influx from voltage-dependent $\mathrm{Ca}^{2+}$ channels or $\mathrm{Ca}^{2+}$ release from the intracellular stores (Collin et al., 2005; Sharma et al., 2008). Deletion of EPAC genes or the interception of EPAC-SUR1 binding increases the open probability of $\mathrm{K}_{\mathrm{ATP}}$ channels in the dentate granule neurons (Fig. $4 D)$. Therefore, it is plausible that EPAC proteins control transmitter release at the granule cell terminals via a direct inhibition of the SUR1 receptor.

Several rare, nonsynonymous variants of EPAC genes have been reported in patients with autism spectrum disorders (Bacchelli et al., 2003), but whether these mutations cause autistic 

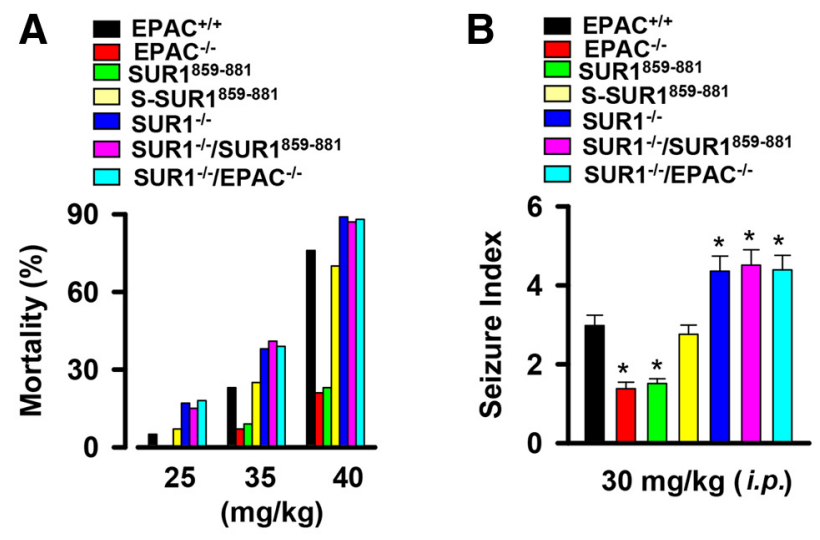

C
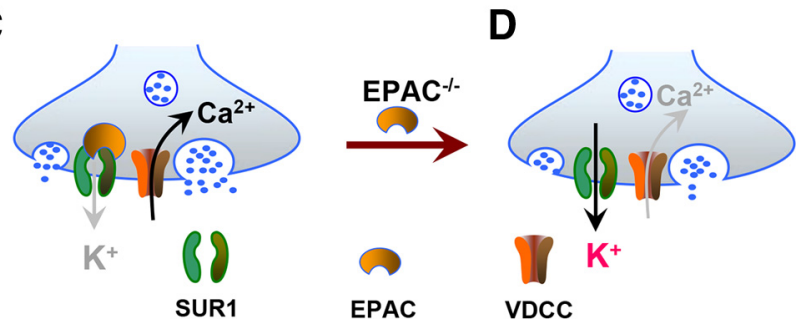

Figure 4. $\mathrm{EPAC}^{-1-}$ mice have decreased vulnerability to epileptic seizures. $\boldsymbol{A}$, Bar graph showing the mortality rate due to convulsive responses within $3 \mathrm{~h}$ after intraperitoneal injection of KA at the doses from 25 to $40 \mathrm{mg} / \mathrm{kg}$. Data are mean \pm SEM ( $n=13$ mice $/$ genotype). $\boldsymbol{B}$, Bar graph showing seizure index after a single intraperitoneal dose of $30 \mathrm{mg} / \mathrm{kg}$. Data are mean \pm SEM ( $n=13$ mice/genotype). C, D, Working model: EPAC controls glutamate release via tonic inhibition of SUR1 receptor at the presynaptic terminals. Opening of Kir6.1/SUR1 channels hyperpolarizes cells, leading to a reduction of $\mathrm{Ca}^{2+}$-dependent transmitter release (C). Deletion of EPAC genes increases the open probability of $K_{\text {ATP }}$ channels in the dentate granule neurons and reduces $\mathrm{Ca}^{2+}$-dependent glutamate release $(\boldsymbol{D})$, thereby antagonizing epileptic seizures.

behaviors remains unknown (Woolfrey et al., 2009). Autism patients are diagnosed with abnormalities of social interactions and mental retardation (Geschwind and Levitt, 2007). Some patients also exhibit spontaneous epileptic seizures (Walsh et al., 2008). Recently, we demonstrated that the EPAC mutation causes defects in spatial learning and social interactions (Yang et al., 2012). In the present study, we have also shown that the EPAC mutation elevates seizure vulnerability. We conclude that disruption of EPAC signaling may represent a molecular mechanism underlying the expression of autistic phenotypes.

\section{References}

Ashcroft FM, Gribble FM (1998) Correlating structure and function in ATP-sensitive $\mathrm{K}^{+}$channels. Trends Neurosci 21:288-294. CrossRef Medline

Bacchelli E, Blasi F, Biondolillo M, Lamb JA, Bonora E, Barnby G, Parr J, Beyer KS, Klauck SM, Poustka A, Bailey AJ, Monaco AP, Maestrini E; International Molecular Genetic Study of Autism Consortium (IMGSAC) (2003) Screening of nine candidate genes for autism on chromosome $2 \mathrm{q}$ reveals rare nonsynonymous variants in the cAMP-GEFII gene. Mol Psychiatry 8:916-924. CrossRef Medline

Ben-Ari Y, Cossart R (2000) Kainate, a double agent that generates seizures: two decades of progress. Trends Neurosci 23:580-587. CrossRef Medline

Bos JL (2006) Epac proteins: multi-purpose cAMP targets. Trends Biochem Sci 31:680-686. CrossRef Medline

Chang N, Liang T, Lin X, Kang Y, Xie H, Feng ZP, Gaisano HY (2011) Syntaxin-1A interacts with distinct domains within nucleotide-binding folds of sulfonylurea receptor 1 to inhibit beta-cell ATP-sensitive potassium channels. J Biol Chem 286:23308-23318. CrossRef Medline

Collin T, Marty A, Llano I (2005) Presynaptic calcium stores and synaptic transmission. Curr Opin Neurobiol 15:275-281. CrossRef Medline de Rooij J, Zwartkruis FJ, Verheijen MH, Cool RH, Nijman SM, Wittinghofer A, Bos JL (1998) Epac is a Rapl guanine-nucleotide-exchange factor directly activated by cyclic AMP. Nature 396:474-477. CrossRef Medline

Geschwind DH, Levitt P (2007) Autism spectrum disorders: developmental disconnection syndromes. Curr Opin Neurobiol 17:103-111. CrossRef Medline

Haucke V, Neher E, Sigrist SJ (2011) Protein scaffolds in the coupling of synaptic exocytosis and endocytosis. Nat Rev Neurosci 12:127-138. CrossRef Medline

Jackson MB, Chapman ER (2008) The fusion pores of $\mathrm{Ca}^{2+}$-triggered exocytosis. Nat Struct Mol Biol 15:684-689. CrossRef Medline

Kawasaki H, Springett GM, Mochizuki N, Toki S, Nakaya M, Matsuda M, Housman DE, Graybiel AM (1998) A family of cAMP-binding proteins that directly activate Rap1. Science 282:2275-2279. CrossRef Medline

Peng PL, Zhong X, Tu W, Soundarapandian MM, Molner P, Zhu D, Lau L, Liu S, Liu F, Lu Y (2006) ADAR2-dependent RNA editing of AMPA receptor subunit GluR2 determines vulnerability of neurons in forebrain ischemia. Neuron 49:719-733. CrossRef Medline

Rehmann H, Prakash B, Wolf E, Rueppel A, de Rooij J, Bos JL, Wittinghofer A (2003) Structure and regulation of the cAMP-binding domains of Epac2. Nat Struct Biol 10:26-32. CrossRef Medline

Sakaba T, Neher E (2003) Direct modulation of synaptic vesicle priming by $\mathrm{GABA}(\mathrm{B})$ receptor activation at a glutamatergic synapse. Nature 424:775-778. CrossRef Medline

Schneggenburger R, Neher E (2005) Presynaptic calcium and control of vesicle fusion. Curr Opin Neurobiol 15:266-274. CrossRef Medline

Schwappach B, Zerangue N, Jan YN, Jan LY (2000) Molecular basis for $\mathrm{K}(\mathrm{ATP})$ assembly: transmembrane interactions mediate association of a $\mathrm{K}+$ channel with an ABC transporter. Neuron 26: 155-167. CrossRef Medline

Sharma G, Grybko M, Vijayaraghavan S (2008) Action potential-independent and nicotinic receptor-mediated concerted release of multiple quanta at hippocampal CA3-mossy fiber synapses. J Neurosci 28:2563-2575. CrossRef Medline

Soundarapandian MM, Wu D, Zhong X, Petralia RS, Peng L, Tu W, Lu Y (2007) Expression of functional Kir6.1 channels regulates glutamate release at CA3 synapses in generation of epileptic form of seizures. J Neurochem 103:1982-1988. CrossRef Medline

Stanley EF (1997) The calcium channel and the organization of the presynaptic transmitter release face. Trends Neurosci 20:404-409. CrossRef Medline

Südhof TC (1995) The synaptic vesicle cycle: a cascade of protein-protein interactions. Nature 375:645-653. CrossRef Medline

Tu W, Xu X, Peng L, Zhong X, Zhang W, Soundarapandian MM, Balel C, Wang M, Jia N, Zhang W, Lew F, Chan SL, Chen Y, Lu Y (2010) DAPK1 interaction with NMDA receptor NR2B subunits mediates brain damage in stroke. Cell 140:222-234. CrossRef Medline

Walsh CA, Morrow EM, Rubenstein JL (2008) Autism and brain development. Cell 135:396-400. CrossRef Medline

Woolfrey KM, Srivastava DP, Photowala H, Yamashita M, Barbolina MV, Cahill ME, Xie Z, Jones KA, Quilliam LA, Prakriya M, Penzes P (2009) Epac2 induces synapse remodeling and depression and its diseaseassociated forms alter spines. Nat Neurosci 12:1275-1284. CrossRef Medline

Yang Y, Shu X, Liu D, Shang Y, Wu Y, Pei L, Xu X, Tian Q, Zhang J, Qian K, Wang YX, Petralia RS, Tu W, Zhu LQ, Wang JZ, Lu Y (2012) EPAC null mutation impairs learning and social interactions via aberrant regulation of miR-124 and Zif268 translation. Neuron 73:774-788. CrossRef Medline

Zhang CL, Katoh M, Shibasaki T, Minami K, Sunaga Y, Takahashi H, Yokoi N, Iwasaki M, Miki T, Seino S (2009) The cAMP sensor Epac2 is a direct target of antidiabetic sulfonylurea drugs. Science 325:607-610. CrossRef Medline

Zhong N, Zucker RS (2005) cAMP acts exchange protein activated by cAMP/cAMP-regulated guanine nucleotide exchange protein to regulate transmitter release at the crayfish neuromuscular junction. J Neurosci 25:208-214. CrossRef Medline

Zhou P, Pang ZP, Yang X, Zhang Y, Rosenmund C, Bacaj T, Südhof TC (2013) Syntaxin-1 N-peptide and $\mathrm{H}(\mathrm{abc})$-domain perform distinct essential functions in synaptic vesicle fusion. EMBO J 32:159-171. CrossRef Medline 